\title{
Conventional or alternative development? Varying meanings and purposes of territorial rural development as a strategy for the Global South
}

\author{
K. Koop \\ University Grenoble Alpes, PACTE, 38000 Grenoble, France \\ Correspondence to: K. Koop (kirsten.koop@ujf-grenoble.fr)
}

Received: 27 August 2013 - Revised: 4 March 2014 - Accepted: 28 April 2014 - Published: 11 December 2014

\begin{abstract}
This paper discusses the increasing interest in the territorial dimension of rural development in the Global South. Adapting the local development approach of the 1970s to the changing context of globalization and to the competitiveness discourse, mainstream development agencies and scholars currently see territorial development (TD) as an attractive model for the integration of rural regions into globalization dynamics. However, territory serves not only conventional mainstream ideologies, but also post-development thinking. It is shown that territory has turned out to be a crucial element for social movements in the defense of alternative visions of modernity and in the constitution of life worlds outside the conventional development path. The analysis of the meaning development actors give the term territory and the focus on the purposes for which it is mobilized allows a variety of possible development paths for the rural South to be identified, thus going beyond the prevailing modernist vision.
\end{abstract}

\section{Introduction}

The renewed interest of scholars in rural development issues in the Global South is marked, among other aspects, by an increasing discussion of its territorial dimension. Territorial development (TD) has even turned out to be an attractive development model for rural regions facing globalization dynamics. Thus, international development agencies such as the World Bank, the Food and Agriculture Organization and the German Gesellschaft fuer Internationale Zusammenarbeit increasingly use the term as a concept when re-thinking local action procedures in the rural South.

Territorial development has clearly found its place in the eclectic landscape of theoretical and conceptual approaches to rural development in the Global South (cf. the article by Rauch in this issue). However, what is actually meant by "territorial"? The growing use of the term in the literature on rural development issues is surprising for two reasons. First, "territory" was long confined to political geography, especially in Anglophone academic communities. The broadening of its semantic spectrum to economic, socio-cultural and development issues is a very recent phenomenon requiring explanation. Secondly, there is a seeming paradox. Territory gained momentum as a political means for international development agencies pursuing a modernist development approach, as well as for social activists and scholars favorable to the idea of post-development. Enhanced integration into global food chains versus the deliberate refusal of inclusion in globalized capitalistic markets - the concept of territory apparently disserves both ideological camps equally.

These are intriguing observations, and lead to a set of questions that will be addressed in this article. What are the driving forces behind the growing interest in territory? How can one and the same concept be applied to such opposing visions of development? What meaning do scholars, development institutions and social movements give to the term? These questions involve the semantics of the term "territory", the sense attributed to it and the underlying visions of development for which it is mobilized.

The first section of this paper argues that the growing attention paid to issues of territory in rural development studies and praxis is a result of the global shift in the way development is conceptualized, or more precisely in the thinking on how development dynamics occur and should be instigated. 
It is argued that the idea of TD falls within the contemporary assumption that sub-national spatial entities constitute an adequate perimeter for political, economic and social rescaling of development processes. It has led mainstream regional science, planning agencies and development cooperation to shift their approach to development from catch-up development at a national scale towards the "integration of regions" within globalized dynamics. The difference between TD and the local development approach of the 1970s and 1980s is then discussed. It is argued that the adaptation of the latter to changing contexts of globalization and to the contemporary competitiveness discourse went along with the mainstreaming of the formally alternative concept.

The second section outlines the ways in which TD is currently conceptualized by scholars and development agencies addressing rural regional development in the Global South. It shows that interpretations of this relatively recent concept vary considerably. A succinct look into the way ongoing TD projects are assessed highlights the argument that TD as a new strategy in development practice does not stand for a fundamental change in the conventional vision of development. It is argued the TD rather represents highly normative discourse and action as part of modernist developmentalism.

In the third part, the paper shows that territory has also become a crucial element for social movements' defense of alternative life worlds. An increasing number of peasantmovement projects are endeavoring to demonstrate that the self-centered use of local resources (such as traditional seeds), combined with social economy systems, can alleviate the often destructive impacts of volatile global markets, transnational firms and genetically manipulated seeds. Territory turned out to be an important dimension for the spatialization of such movements' identity and for constituting a political strategy for the defense of their "otherness". The scrutiny of alternative rural TD projects, such as the Navdanya Indian peasant movement, shows that the territorial rural development approach is used in a version much closer to the original local development concept. It is argued, however, that these alternative territorial projects do constitute a novelty in the sense that they do not aim at development according to the conventional regime of modernity.

The capacity the mobilization of territory has to reveal alternative life worlds shows that it is interesting for future research to go beyond the ongoing theoretical discussions on the etymology of territory. Studying the varying meanings actors in development attribute to the term according to their systems of reference allows one to discern the plurality of possible development paths beyond conventional modernity.

\section{The global change in the conception of how development occurs}

To understand the reasons for the renewed interest in territory as a rural development model for the so-called develop- ing countries, it has to be seen in its broader historical and global context, i.e., the current assumption that sub-national spatial entities constitute an adequate perimeter for political rescaling and development in an era of globalization.

Within the academic field of regional studies, this represented a considerable shift, not only in scale but also in the view of how development should occur and be stimulated: from catch-up development at a national level to the integration of regions into globalized dynamics (Koop, 2007). Leaving behind the well-established post-war model of industrialization at national scales, scholars and planners have discovered the sub-national region to be the "nodal point of critical development and growth processes" (Scott and Storper, 2003:32) and the "space for the action of states and for political mobilisation [and] for economic change" (Keating and Loughlin, 1997:11).

Spatial economy studies were revived from the early 1990s on. In an attempt to overcome the analytical challenge of situating regional development between the local and the global, research re-concentrated on the potential effects of economic agglomeration and proximity as well as endogenous dynamics of economic development (Benko, 1995). We then witnessed an extraordinary explosion of studies on the drivers of regional development. Internationally shared key regional concepts include Marshall's revised industrial districts (Marshall, 1961), clusters (Porter, 1990), local production systems (Colletis et al., 1990), innovative networks (Camagni, 1991) and the innovative environment (Aydalot, 1985), new regionalism (Keating and Loughlin, 1997; MacLeod, 2001) and, finally, territorial development (Pecqueur, 2005, 2008) - to mention but the most relevant.

Despite the wide spectrum of theoretical and conceptual approaches, the different development models share a number of common underlying principles, helping to analyze the dynamics of regions at the crossroads between specific endogenous, locally fixed dynamics, and global flows and networks. The multi-scalar approach, providing the means to identify the potentials and constraints of regions/territories in their interrelations with national, supranational and global dynamics, has turned out to be indispensable. Likewise, the systemic approach, allowing the integration of economic, political, social, cultural and/or environmental issues, has undeniably turned out to be a necessary approach to addressing the complexity and multidimensionality of regions (see, for example, Esser et al., 1996). The emergence of the public sector and civil society as new development actors, linked to spatial considerations of regional proximity, inter-relationships and cooperation, gave rise to efforts to conceptualize governance at a regional level (MacLeod and Goodwin, 1999). Since the crucial work of Castells (1996), networking has proved to be one of the major viable approaches in the search for the optimal form of organization enabling the shift from state-centered government towards actor-oriented governance (Bauer-Wolf et al., 2008). 
Regional studies and planning writing on the global rescaling of economic and governance dynamics addresses the subnational scale either as local, regional or territorial. It is not the aim of this article - and it is scarcely even possible - to describe the differences in the definitions and meanings attached to these terms, as each differs in time and space. The aim here is to point out the recent inroads of the term territory into regional studies and planning, and the major meanings attributed to the term. Here again, interpretations and semantic meanings are manifold. It is possible, however, to discern several essential common points.

In the English-language literature, where the term region prevails, the term territory becomes an issue whenever the question of local or regional rescaling and re-embedding of national political power and control is addressed, following Brenner's rescaling of the state discussion (Agnew, 1994, 2010; Brenner and Theodore, 2002; Brenner, 2004; Elden, 2010; Keating and Loughlin, 1997). This is not surprising, as the traditional legal-political meaning of territory is not questioned here. More closely related to our discussion is the observation that the term territory appears in publications discussing the local anchoring and embedding of the economic or social dynamics of development (Jonas, 2010; Kappel, 1995; Krätke, 1995), and refers to "particular administrative, political, social and cultural forms and identities" (Pike et al., 2007:1258). However, this terminological shift most often lacks explanation, and it is easy to agree with Jonas, who deplores the lack of "any serious discussion of territory and territoriality in the debate about regions" (Jonas, 2010:2).

At the same time, French and Italian scholars, influencing Spanish and Brazilian ones (cf. Raffestin, 1980; Pecqueur, 1989), have produced an abundant, rich literature on the concept of territory as a development model. In France - even if a wide range of interpretations of its meaning is still to be seen in academic writing - territory has definitively been taken out of its political realm in planning practice and been transformed into a holistic concept embracing social, historical, economic and political dimensions equally, while also replacing the term region. It is considered a "socially produced and appropriated space, to the point where it constitutes, at the same time, an identity referent, a framework for regulations, and an area for public action" (Vanier, 2008). This interpretation leads to the consideration of territory as a complex social construct, rather than a surface onto which local action is projected, but this might not yet constitute a major difference with the global spectrum of related concepts, as nearly all of them no longer consider the region as a passive receptacle of and for the globalized economy. A more essential difference seems to lie in the much profounder conceptualization of the (possible) endogenous character of economic development. The process of identifying local resources by local stakeholders is an important research issue in French and Italian regional science. Such resources may be material or immaterial (skills, know-how), already existing or po- tential, generic (e.g., mining resources) or specific. The concept of territorial specificity (Pecqueur, 2005, 2008), based on Hirschman's work on the revealing of local latent, unexploited resources (Hirschman, 1964), could be considered the most refined effort in the French debate to conceptualize the territorial dimension of economic development. Local actors, their forms of organization and coordination and the creation of resources (as both a process and a result) are considered to be strongly related to a specific territorial identity, with its history, heritage and know-how. Pecqueur shows that the resource itself, as well as the way it is revealed, can and should reach such a degree of territorial specificity that the product can escape international competition, since it cannot be reproduced elsewhere. In the same vein, Camagni's work on territorial capital strongly asserts specific territorial context and identity (Camagni, 2009).

It is not surprising to observe that this way of conceptualizing TD has infiltrated and is currently taking over the regional development discourse in Western planning agencies. The European Union and the OECD, for example, increasingly recognize the important (economic) development opportunities that can be identified by revealing the specific characteristics of a given region in order to enhance its competitiveness (Campollo and Nijkamp, 2009:3; OECD, 2001). In the same vein, the EU's territorial cohesion agenda for 2020 stresses the endogenous potential of its regions to create innovation clusters.

The reader may already have noticed that territorial development (TD) ties in with some essential ideas of the local development approach of the 1970s and 1980s. In fact, the roots and scientific underpinnings of TD are to be found in the internationally recognized writings Development from above or below. The Dialectics of Regional Planning in Developing Countries (Stöhr and Taylor, 1981) and Territory and Function. The Evolution of Regional Planning (Friedmann and Weaver, 1979) ${ }^{1}$. Local development, also known as the "development from below" approach, was closely linked to the spirit of the dependency theories dominating critical development studies during the 1970s and 1980s. Promoting endogenous dynamics and focusing on self-reliance, autonomy and sealing off from global markets, it was considered the optimal response to local needs in marginalized rural regions in the Global South as well as in peripheral regions of the Occident (such as industrial regions in crisis). At the time, its main new feature was to turn away from the sectoral, top-down policies of the state, considered incapable of taking into consideration local historical and cultural contexts

\footnotetext{
${ }^{1}$ It should be mentioned that even then, the terms "local", "region" and "territory" were often used indiscriminately when referring to alternative concepts of spatial development. Thus, Friedman already uses the term "territory" when addressing rural development as "responsive to the needs of rural people" and "compatible with local conditions and physical environment" (Friedman, 1981:1).
} 
Table 1. From local to territorial development.

\begin{tabular}{ll}
\hline Local development approach of the 1970s/1980s & $\begin{array}{l}\text { Mainstream contemporary territorial development } \\
\text { approach }\end{array}$ \\
\hline $\begin{array}{l}\text { Mono-scalar approach } \\
\text { Aims at fostering local production and consumption circuits, } \\
\text { self-reliance and self-sufficiency }\end{array}$ & $\begin{array}{l}\text { Multi-scalar approach } \\
\text { Aims at integrating markets at different scales }\end{array}$ \\
\hline Mobilization of local resources as a response to local needs & $\begin{array}{l}\text { Revelation of specific resources to meet national and } \\
\text { international competitiveness }\end{array}$ \\
\hline State and local/regional administration as major actor & $\begin{array}{l}\text { Integration of new types of stakeholders into local/regional } \\
\text { governance }\end{array}$ \\
\hline
\end{tabular}

Source: Koop et al. (2010)

and including poor and vulnerable stakeholders in development dynamics (Rauch and Redder, 1987) ${ }^{2}$.

Despite essential common elements, the current idea of TD differs from local development (Table 1). First, endogenous economic development at the local level is no longer thought to consist of fostering self-reliant production and consumption in order to reduce dependency on global markets. In a world of economic liberalization, development is conceptualized in terms of links with other scales, introducing the idea of economic competitiveness by adjusting production and selling to external markets ("coping with markets", Rauch, 1996). A second fundamental change is the emergence of new systems of governance. Development at sub-national level is no longer considered a state monopoly. Local development initiatives are considered to result from coordination between the public sector, private stakeholders and civil society, including traditional, informal actors. The third difference lies in the idea that it is less the optimal allocation of existing resources that is at stake, but rather their creation through the valorization of specific territorial potentials by mobilizing local history, culture, specific knowhow, networks and common identity (Adelmalki and Courlet, 1996:18).

The analysis of this "updating" and adjustment of local development to changing external development conditions since enhanced globalization shows that it consented to dropping its alternative connotations. In contemporary regional science and Western development agencies, TD represents a modernist development strategy aiming at the economic integration of regions into the conventional regime of capitalist

\footnotetext{
${ }^{2}$ German development cooperation transposed the basic ideas of this concept into Laendliche Regionalentwicklung (regional rural development). As the expression local development then largely dominated in the English-language literature, it will be adopted here. Distinguishing the meanings of local development and territorial development also facilitates the comprehension of the recent intensified discussion of the necessity for an explicit shift from local and region towards territory as a fundamentally new analytical category and development model.
}

global markets. It is this new mainstreamed version of local development that is today being transferred to the Global South, especially towards rural regions, through international cooperation programs along with ongoing decentralization processes.

\section{The meanings and use of territory in development practice in the Global South}

Many Latin American countries such as Brazil and Chile have been following a distinctly territorial approach since the late 1990s. Africa is also benefiting from numerous programs explicitly transferring the idea of TD towards regional planning practices, such as the African Partnership for Municipal Development initiative or the Fond de Solidarité Prioritaire with Morocco and Algeria, initiated by the French cooperation program and the World Bank in 1994. Like the local development approach of the 1980s, the territorial approach to rural regional development in the Global South is considered to have major advantages. Firstly, it is said that local needs and particularities, systematically neglected by national public policies for so long, can be taken into consideration. Even the often ignored mismatch between formal and informal administrative systems, such as traditional chieftaincy, becomes a factor to take into account (Giraut, 2000). Furthermore, the participation of the whole set of stakeholders in prospective TD plans is seen as a chance for a fruitful collective debate on the fundamental options for development at the local level and to stimulate collective identification with development projects (Alvergne, 2008:173; GIZ, 2011).

Before confronting these theoretical considerations with real opportunities and limits, however, it is important to understand how international development agencies and scholars working in the field interpret the territorial dimension of development and what strategies they associate with it. What kind of development is TD supposed to induce? Which rural stakeholders are supposed to benefit? What role is given to poor peasant farmers? To what extent are social and environmental issues integrated into the territorial approach? 
The ongoing discussions on TD as a model for rural regions in the Global South range from the strictly rhetorical and communicational to a serious concern for the new paths the concept has opened up. In the recent literature, the underlying purpose is as univocal as vague: the reduction of rural poverty and inequalities is explicitly declared as the overall aim. In order to analyze how the territorial dimension of development is actually interpreted, however, we need to examine what are put forward as the levers of such poverty and inequality reduction. We then find a wide spectrum of interpretations. Some development institutions seem to take the new discourse on TD as a simple opportunity to update the list of issues to be tackled by development cooperation programs. In this vein, new issues engendered by the rapidly changing context of rural development are addressed, such as ruralurban links (Janvry and Sadoulet, 2007), land tenure (FAO, 2005), new institutional arrangements, governance and climate change (GIZ, 2011). Methodological project tools are revised along with this, as shown by the emphasis on multiscalar, multi-stakeholder and cross-sectoral approaches. The need for a semantic switch from the former regional to the new territorial development - which would be legitimate in order to announce a conceptual change or even a mere adjustment in paradigm - is not obvious here.

Other agencies and scholars do address territorial issues much more explicitly. The World Development Report of 2008 on Agriculture for Development, for instance, addresses TD strategies as including "the promotion of local agrobased clusters where agricultural producers and agroindustries [...] interact to better compete", and designates innovation and local spillovers "as a driver of local growth" (World Bank, 2007:221). Market integration, through the traditional set of strategies and policies (institution building, securing rights, training, the use of information and communication technology (ICT) and so on), concerns not only large and medium enterprises, but is also seen as a solution for smallholders. In the same vein, other authors recommend fostering local entrepreneurship and interpret the territorial dimension by recommending a closer look into endogenous growth potential and underused resources (Janvry and Sadoulet, 2004; Quan et al., 2006; Schejtman and Berdegué, 2008). TD appears here as a new strategy opening ways for economic development and integration into global networks.

Within this conventional approach, the potential of the term territory to conceptualize rural development in the Global South does not seem to have been fully exploited. Essential ideas related to territory such as local history and identity, local synergies and the revelation of local resources are mentioned but barely discussed. However, interpreting territory as a social construct would inevitably raise questions about local social and power relationships. This crucial but highly sensitive issue is rarely addressed. Only the FAO considers TD to be "social change processes" and has made a serious attempt to transpose the idea into its operational tool, participatory and negotiated territorial devel- opment (PNTD). PNTD explicitly addresses power asymmetries, with the goal of "supporting a process aiming at the creation of socially legitimized agreements by involving all stakeholders and leading to their commitment and ownership over the development process" (FAO, 2005:11).

Whatever critiques could be made of its conceptualization, the practical application of the TD concept in ongoing programs in Latin America and Africa also requires closer examination. An often-cited major constraint is the weakness of local institutional capacities. Even if positive examples do exist, African case studies are said to have revealed that institutional maturity at the various sub-national scales - an indispensable precondition for effective rural governance and development - has not been reached. In fact, ongoing decentralization processes are often assessed as deconcentrating rather than decentralizing public power and responsibilities. These relatively young institutions are said to continue to suffer from a lack of financial and logistical support as well as planning skills and decisional autonomy (Landel, 2011:49; GIZ, 2011:13). In addition, well-known local governance problems, such as the lack of local public-sector legitimacy, mediation capacities and willingness, along with contradictions between traditional and public-sector management systems (e.g., land management), are considered shortcomings that still have to be overcome.

Such kinds of observations do address deficiencies in relation to optimal conditions for territorial development in the rural South. They reveal that TD as a strategy is highly normative and bound to the conventional concept of development as modernization. Modernist development, focusing on enhancing economic dynamics, is seen as the means for tackling poverty and inequalities. Its links with and fallout on social and environmental issues, however, are hardly clarified.

\section{Escaping from development path dependency: the territorial dimension of alternative life worlds}

If one adheres to critical theories of world capitalist development such as the "uneven development" of Neil Smith (1984) or the "fragmenting development" of Fred Scholz (2005), who argue that globalized capitalism constantly creates spaces of inclusion as well as exclusion, and that poverty and wealth are two sides of the same coin, TD can easily be considered a "political development therapy of symptoms" (Mueller-Mahn and Verne, 2010:6), stuck within conventional modernist dichotomist thinking and therefore not allowing other imaginings of being and living (together) to be perceived and recognized. Territorial rural development as a strategy might thus reach out to modernize one or another region of the rural South, but does no alternative exist between integrating global value chains and being part of the "new periphery [...], largely left to itself, [wearing] itself out with inner contradictions, suffer [ing] from poverty and backwardness" (Scholz, 2005:10)? As Scholz points out, the so-called 
periphery may also (re)create new, alternative lifestyles. In this line of thinking, it is interesting to look more closely into post-development thinking and its local grassroots projects currently burgeoning around the world.

Postcolonial and post-development scholars would no doubt designate TD as a strategy trapped inside the Western doctrine of modernity. Undeniably, TD aims at development, an idea deeply anchored in Western teleological thinking, anthropocentrism and economic essentialism. According to the post-development school, development as a world view, dominant discourse and project of the West constitutes - to keep it brief - the "problem not the solution" (Rist, 1997; see also Escobar, 2001, 2008; Esteva and Prakash, 1998; Rahmena and Bawtree, 1997; for a critical discussion, see Sidaway, 2007). The practical expressions of this radical calling into question of development are local grassroots projects, instigated by local civil society, NGOs and social movements. These are based on community, autonomy and participation, and are deeply anchored in the cultural, historical and local (Esteva and Prakash, 1998). While postmodernist thinkers have long been criticized for not coming up with viable alternatives, and said to produce an "agendaless academic cul-de-sac" (Blaikie, 2000:1033), such alternative projects are actually mushrooming all over the world, especially in rural regions of Latin America and India. Ongoing projects nowadays demonstrate the emergence of nonmodernist norms and value systems, while their viability can at least be discussed. There is no evidence yet, but some authors have aimed to show that such local systems may favor the alleviation of the often destructive impacts of volatile global markets, transnational firms and genetically manipulated seeds, as well as enhance resilience to climate change (Inter Pares, 2004). Well-known examples attracting international attention are the Indian Navdanya movement and the Dekkan Development Society (DDS), Afro-Colombian communities of the Pacific and the Movimento dos Trabalhadores Sem Terra (MST). Lots are located in rural areas of the Global South, focusing on community-controlled organic agriculture, food sovereignty and biodiversity conservation (Shiva, 2008). The core value system of such alternatives clearly differs from Euro-American modernity. Circular thinking, the subordination of economic objectives to ecological criteria (bio-centrism), spirituality, human dignity and well-being indicate concrete practical paths towards civilizational transformation that can no longer be ignored.

In order to perceive and recognize such emerging life worlds, we first need to rid ourselves of the binary worldview imposed by Western modernity. In fact, the usual terms such as "under-developed", "less developed", "developing", "peripheral", "marginal" or "excluded" attributed to areas of the Global South are all just expressions of our normative Western (one-world) view. The matter is to recognize these life worlds as reals, as "different realities being done in different practices" (Law, 2011:2) - and not as the negation of modernity as such, but as other, alternative (post)modernities.
Like regional science, the post-development school has developed a set of analytical tools to analyze such local schemes to constitute and defend otherness. Actor-network theory has long dominated (Law and Hassard, 1999), helping to theorize both horizontal networking and its translocal character. Place and place-making have then come to be considered important in understanding the questions of identity, history and political strategies as essential elements of the (re)creation of specific life worlds (see Escobar, 2001). However, it is the growing number of recent works stressing the territorial dimension of social (often indigenous) movements that attracts our attention here (Offen, 2003; Escobar, 2008; Perreault and Green, 2013; Salisbury, 2013).

Unlike TD, which can be seen as a development strategy imposed by external actors on local people, the recent importance scholars have given to territory is linked to its use by the local protagonists of social change (or indeed development) themselves. Land titling has long been a major strategy in the struggle and resistance against external onslaught exercised by either the state, the public sector or development agencies. Escobar (2008) and Offen (2003) were two of the first scholars to point out the switch to a territorial strategy in Latin America during the 1990s. The emerging territorial discourse of indigenous movements includes not only the idea of land re-appropriation, but also those of the control of land (terra), boundary fixing and the constitution of new forms of governance. It went along with evincing "the development of spatial consciousness among movement activists" (Escobar, 2008:62) and the (re)construction of a "place-based identity, linking history, culture, environment and social life". Social movements' territories can thus be considered the "embodiment of the life project of a community" (Escobar, 2008:59). It is in this sense that territory should be essential to emancipation from Western modernity and the process of alternative identity (re)construction, interrupting the One-World project of Occidental modernity (Escobar, lecture in Grenoble, France, 11 June 2013). The fact that territory is mobilized here as a political strategy for the defense of the right to another vision of the world can only be understood in relation to the external "context that rewards such modes of political articulation" (Offen, 2003:66). Such territories might then be conceived as "emerging extra-state identity communities" (Murphy, 2010:771) or as part of the "specialized assemblages of territory, authority and rights" that are discussed by Sassen (2006). According to the author, such assemblages appear and multiply at sub-national and supranational scales due to the "privatization of the capacity to produce norms" in times of globalization (Sassen, 2006:372).

After this brief discussion of the territorial dimensions of projects of alternative (post)modernities, I would like to return to their dimension of development. Even though post-development scholars reject the very idea of development, others warn that the baby should not be thrown out with the bathwater, and plead for "imagining and practicing 
Table 2. Mainstream territorial development versus alternative territorial development.

\begin{tabular}{|c|c|}
\hline Mainstream territorial development & Alternative territorial development \\
\hline Based on modernist vision of development & Based on alternative visions of development \\
\hline Economy centered & Socio and bio-centered \\
\hline Systemic & Holistic \\
\hline Multi-scalar approach & $\begin{array}{l}\text { Local and multi-scalar approach (integration into "alternative" } \\
\text { global information networks and economic markets) }\end{array}$ \\
\hline $\begin{array}{l}\text { Revelation of specific local economic resources to meet } \\
\text { national and international competitiveness }\end{array}$ & $\begin{array}{l}\text { Revelation/re-appropriation of local natural, spiritual, cultural and } \\
\text { economic resources to meet local well-being }\end{array}$ \\
\hline $\begin{array}{l}\text { Integration of new types of stakeholders into local/regional } \\
\text { public governance }\end{array}$ & $\begin{array}{l}\text { Community-based governance } \\
\text { Deliberate exclusion of transnational companies } \\
\text { Negotiation with state for recognition of alternative value system }\end{array}$ \\
\hline Homogenization & Diversity, through re-appropriation of cultural identity \\
\hline $\begin{array}{l}\text { Use of territory to foster endogenous (economic) dynamics for } \\
\text { modernization }\end{array}$ & Use of territory for defense of "otherness" (political ontology) \\
\hline
\end{tabular}

Source: Koop, following Escobar (2008); Koop et al. (2010); Pecqueur (2008); Shiva (2008)

development differently" (Gibson-Graham, 2005:6; Pieterse, 2000). By adapting this position here, such grassroots projects could be termed alternative territorial development (ATD), in the sense of creating and defending life worlds outside Western modern thinking.

At first sight, ATD comes much closer to the original version of local development than the mainstream(ed) TD approach (see Table 2). In fact, the original ideas of community-centered self-reliance, by sealing oneself off from the (destructive) world market, have antithetically survived the doctrine of the neoliberal global economy. However, considering ATD as a simple resurgence of old ideas expressed since the 1970s (see Stöhr and Taylor, 1981, and Friedman and Weaver, 1979) runs the risk of not understanding its essential novelties.

Despite its alternative character, local development during the 1970s and 1980s was most often seen as a step towards Western modernity, as it implicitly followed the overall idea of the catch-up development of "underdeveloped" regions. The main novelty of ATD lies in its radical refusal of that vision. Numerous projects emphasize their explicit rejection of some basic pillars of Euro-American modernity, including the ideas of linear thinking, progress, materialism, economic market orientation, competition and so on. ATD can thus rather be considered the careful choice and specific blending of pre-modern vernacular knowledge and being with elements of Euro-American modernity (such as communication technologies), according to a more holistic, socio- and biocentered vision, re-embedding the economy within society.

Unlike the former local development, such ATD approaches are deeply rooted in multi-scalar perspectives. The strength of the Navdanya experiment of traditional seed banks and the defense of their territories against multinational firms, for instance, lies not only in the fact that it covers a growing network of interlinked village communities at the national scale, but that it is located in a framework of global networks, including other social movements, external councilors and economic and scientific advisers worldwide. It is clear that new technologies and cyberspace play an important role in such global networking. Recent evolutions also show that, even if self-sufficiency and food autonomy are major aims of many rural ATD programs, this does not exclude economic integration into national or global alternative economic markets. As part of the international slow food movement, Navdanya has opened a slow food café in Delhi. It also links farmers to co-producers through fair trade initiatives.

Such alternative territorial development thus implies the rejection of neither globalization nor modernity per se. It should be seen as another articulation of the social, the economic and the natural within globalization and modernity, contributing to ecological and cultural transitions. Recognizing this ontological struggle of peasant and/or indigenous communities - without romancing - means acknowledging that rural development in the Global South might be pluriverse (Escobar, 2011) and does not exclusively follow the trajectory of conventional modernization.

\section{Conclusions}

The increasing interest in the territorial dimension of rural development in the Global South expresses the awareness that the sub-national level is an important, if not the crucial, 
scale to be considered when analyzing and conceptualizing development in times of globalization. The fact that both modernization and alternative development projects mobilize the idea of territory should not be perceived as a paradox. They have in common the fact of responding to the changing contexts of rural livelihoods and to the contemporary complexity of rural situations. In both cases, the territorial lens brings in the local stakeholders and induces a re-thinking of local action procedures.

The paper has shown that development praxis and research on rural development attribute a wide range of meanings to the term. Its political dimension stays highly relevant, but the term can no longer be confined to it. Conventional rural TD approaches rather use territory to rethink local economic processes as well as local governance issues. In the case of social movements struggling for emancipation from Western modernity, the political and social dimensions of territory are at stake. The varying interpretations reveal that we should not be bound by the term and its definitions. Especially the challenge of understanding the territorial dimension of social movements' life worlds leads one to pay more attention to the purpose for which development actors do mobilize territory according to their reference and value systems. In fact, it has been shown that the overall objective and the vision of development of both local communities and development agencies highly determine the meaning given to the term and its use.

The paper has also outlined the fact that for social movements, territory does not only disserve alternative life world imaginings, but also constitutes an integral part of the development strategy itself. As the implementation of alternative ways of living often presupposes control over physical space, a major step of such community-based projects is the legal acquisition of land titles, followed then by the fight for acknowledgement within the formal legal system. This strategy shows that the right to existence of these communities which paradoxically often do not include land property rights in their own world vision - within the dominant system can only be reached by dealing with the norms of the contested conventional regime. Interestingly, the use of territory as a political strategy then fosters their own territorialization process: the construction of a shared local history and placebased collective identity.

The social movements' use of territory as political ontology helps to reveal the still often ignored diverse life worlds outside the one that determines Occidental development practice. In order to accept pluriversality, in the sense of pre-modern, modern and postmodern forms of existence and their multiple hybrids, the overall aim of rural development projects in the Global South should thus always be defined by the local actors at stake and be negotiated in each case. Collective reflections on territory, as the embodiment of rural development projects, are then useful for clarifying and defining the purpose and underlying vision of such projects.
Acknowledgements. Parts of this paper are based on ideas co-constructed and written down with my colleague Anne-Laure Amilhat-Szary. I thank her for her collaboration as well as Alexander Murphy for the fertile insights he provided from his reading of our initial text. I am also deeply grateful to Arturo Escobar for the inspiring discussions with him during his stay in Grenoble in June 2013.

Edited by: B. Korf

Reviewed by: two anonymous referees

\section{References}

Abdelmalki, L. and Courlet, C.: Les nouvelles logiques du développement territorial, L'Harmattan, Logiques économiques, Paris, 1996.

Agnew, J. A.: The Territorial Trap: The Geographical Assumptions of International Relations Theory', Rev. Int. Polit. Econ., 1, 5380, 1994.

Agnew, J.: Still Trapped in Territory?, Geopolitics, 15, 779-784, 2010.

Alvergne, C.: Le défi des territoires. Comment dépasser les disparités spatiales en Afrique de l'Ouest et du Centre, Karthala/PDM, Paris/Cotonou, 2008.

Aydalot, P.: Economie régionale et urbaine, Economica, Paris, 1985.

Bauer-Wolf, S., Payer, H., and Scheer, G. (Eds.): Erfolgreich durch Netzwerkkompetenz. Handbuch für Regionalentwicklung, Springer, Vienna, 2008.

Benko, G.: Les chemins du développement régional : du global au local, Multitudes, 1995.

Blaikie, P.: Development, post-, anti-, and populist: a critical review, Environ. Plann., A 32, 1033-1050, 2000.

Brenner, N.: New State Space: Urban Governance and the Rescaling of Statehood, Oxford University Press, Oxford, 2004.

Brenner, N. and Theodore, N.: Preface: from the "new localism" to the spaces of neoliberalism, Antipode, 34, 341-347, 2002.

Camagni, R. (Ed.): Innovation Networks: Spatial Perspectives, Belhaven Press, London, 1991.

Camagni, R.: Territorial Capital and Regional Development, in: Handbook of Regional Growth and Development Theories, Edward Elger Publishing, Cheltenham/Northampton, 118-132, 2009.

Capollo, R. and Nijkamp, P. (Eds.): Handbook of Regional Growth and Development Theories, Edward Elgar Publishing, Cheltenham/Northampton, 2009.

Castells, M.: The Rise of the Network Society, U.S.: Blackwell Publishing, 1996.

Colletis, G., Courlet, C., Pecqueur, B., and Winterhalter, F. (Eds): Les systèmes industriels localisés (politiques publiques et systèmes industriels localisés en France, Italie et R.F.A.) Grenoble, IREPD, 1990.

Deutsche Gesellschaft für Internationale Zusammenarbeit - GIZ: Neues entwickeln. Territoriale Entwicklung im ländlichen Raum. Entwicklung ländlicher Räume - von Bewährtem lernen, Eschborn, 2011.

Elden, S.: Land, Terrain, Territory, Prog. Hum. Geogr., first published on 21 April 2010. 
Escobar, A.: Culture Sits in Places: Reflections on Globalism and Subaltern Strategies of Localization, Polit. Geogr., 20, 139-174, 2001.

Escobar, A.: Territories of Difference. Place, Movements, Life, Redes, Duke University Press, Durham/London, 2008.

Escobar, A.: Sustainability: Design for the Pluriverse, Development, 54, 137-140, 2011.

Esser, K., Hillebrand, W., Messner, D., and Meyer-Stamer, J. (Eds.): Systemic Competitiveness. New Governance Patterns for Industrial Development, Routledge/Frank Cass., London/Oregon, 1996.

Esteva, G. and Prakash, M. S. (Eds.): Grassroots Post-Modernism: Remaking the Soil of Cultures, Zed Books, London and New York, 1998.

Food and Agriculture Organisation - FAO: An approach to Rural Development: Participatory and Negotiated Territorial Development (PNTD), Rural Development Division, Geneva, 2005.

Friedmann, J.: The Active Community: Toward a PoliticalTerritorial Framework for Rural Development in Asia, Econ. Dev. Cult. Change, 29, 235-261, 1981.

Friedmann, J. and Weaver, C.: Territory and Function: The Evolution of Regional Planning, University of California Press, Berkeley and Los Angeles, 1979.

Gibson-Graham, J.-K.: Surplus Possibilities: Postdevelopment and Community Economies, Singapore J. Trop. Geo., 26, 4-26, 2005.

Giraut, F.: Innovation territoriale et référent communautaire. Du renouveau des provinces nigériennes à celui des pays français, in: Politiques et dynamiques territoriales dans les pays du Sud, Publications de la Sorbonne, Paris, 77-108, 2000.

Hirschman, A. O.: La stratégie du développement économique, Les Editions Ouvrières, Paris, 1964 [1958].

Inter Pares: Community-Based Food Security Systems. Local Solutions for Ending Chronic Hunger and Promoting Rural Development, Inter Pares Occasional Paper, 4, 2004.

Janvry, A. and Sadoulet, E.: Toward a Territorial Approach to Rural Development: International Experiences and Implications for Mexico's Microregions Strategy, University of California at Berkeley, July 2004.

Jonas, A. E. G.: Region and Place: Regionalism in Question, Prog. Hum. Geog., Progress Report, 36, 263-272, 2010.

Kappel, R.: Kern und Rand in der globalen Ordnung - Globalisierung, Tripolarität, Territorium und Peripherisierung, Peripherie, 15(59/60), 79-117, 1995.

Keating, M. and Loughlin, J.: The Political Economy of Regionalism, Robert Schuman Centre, 1997.

Koop, K.: Les nouvelles fractures du monde et le défi pour la recherche sur les inégalités de développement, Cahiers du GEMDEV, 31, 182-195, 2007.

Koop, K., Landel, P. A., and Pecqueur, B.: Pourquoi croire au modèle du développement territorial au Maghreb ? Une approche critique, EchoGéo, 13, doi:10.4000/echogeo.12065 (last access: 20 May 2014), 2010.

Krätke, S.: Globalisierung und Regionalisierung, Zeitschrift für Wirtschaftsgeographie, 83, 207-221, 1995.

Landel, P. A.: L'exportation du " développement territorial " vers le Maghreb : du transfert à la capitalisation des expériences, L'Information Géographique, 4, 39-57, 2011.

Law, J.: What's Wrong with a One-World World, Heterogeneities.net, 2011, Online journal, avail- able at: http://www.heterogeneities.net/publications/ Law2011WhatsWrongWithAOneWorldWorld.pdf, last access: 25 June 2013.

Law, J. and Hassard, J.: Actor-Network Theory and After, Oxford, Blackwell/Sociological Review, 1999.

Mac Leod, G. and Goodwin, M.: Space, Scale and State Strategy: Rethinking Urban and Regional Governance, Prog. Hum. Geog., 23, 503-527, 1999.

Marshall, A.: Principles of Economics, Macmilla, London, 1961.

Mueller-Mahn, D. and Verne, J.: Geographische Entwicklungsforschung - alte Probleme, neue Perspektive, Geographische Rundschau, 10, 4-11, 2010.

Murphy, A. B.: Identity and Territory, Geopolitics, 15, 769-772, 2010.

OECD: The OCDE Territorial Outlook 2001: Making Sense of the Maze, OECD, Paris, 2001.

Offen, K.: The Territorial Turn: Making Black Territories in Pacific Colombia, Journal of Latin American Geography, 2, 43-73, 2003.

Pecqueur, B.: Le développement local, Syros, Alternatives Economiques, Paris, 1989.

Pecqueur, B.: Le développement territorial, une nouvelle approche des processus du développement pour les économies du Sud, in: Le territoire est mort, vive les territoires ! Une (re)fabrication au nom du développement, IRD Edition, Paris, 295-316, 2005.

Pecqueur, B.: Territorial Dynamics: Towards a New Model of Development Facing Globalization, in: Networks, Governance and Economic Development, Bridging Disciplinary Frontiers, edited by: Aranguren, M. J., Iturrioz, C., and Wilson, J. R., Edward Elgar, London, 30-39, 2008.

Perreault, T. and Green, B.: Reworking the Spaces of Indigeneity: the Bolivian Ayllu and Lowland Autonomy Movements Compared, Environ. Plann. D, 31, 43-60, 2013.

Pieterse, J. N.: After Post-Development, Third World Q., 21, 175191, 2000.

Pike, A., Rodriguez-Pose, A., and Tommaney, J.: What Kind of Local and Regional Development and for Whom ?, Reg. Stud., 41, 1253-1269, 2007.

Porter, M. E.: The Competitive Advantage of Nations, Free Press, New York, 1990.

Quan, J., Davis J., and Proctor, F.: Rural Development from a Territorial Perspective: Lessons and Potential in Sub-Saharan Africa, International Development Research Centre, Ottawa, Canada, 2006.

Raffestin, C.: Pour une géographie du pouvoir, Libraires techniques, Paris, 1980.

Rahnema, M. and Bawtree, V. (Eds.): The Post-Development Reader, Zed Books, London and New York, 1997.

Rauch, T. and Redder, A.: Autozentrierte Entwicklung in ressourcenarmen ländlichen Regionen durch kleinräumige Wirtschaftskreisläufe, Die Erde, 118, 109-126, 1987.

Rauch, T.: Ländliche Regionalentwicklung im Spannungsfeld zwischen Weltmarkt, Staatsmacht und kleinbäuerlichen Strategien, Verlag für Entwicklungspolitik, Saarbrücken, 1996.

Rauch, T., Bartels, M., and Engel, A. (Eds.): Regional Rural Development. A Regional Response to Rural Poverty, Schriftenreihe der GTZ, 274, Universum Verlagsanstalt, Wiesbaden, 2001.

Rist, G.: The History of Development: From Western Origins to Global Faith, Zed Books, London and New York, 1997. 
Salisbury, D.: Changing Conceptions of Territory among Indigenous Peoples and Social Movements of the Peruvian Amazon, paper session "Territory, Conflict, Resources: Dynamism in indigenous spaces and social movements", AAG, 04/12/2013.

Sassen, S.: Critique de l'Etat. Territoire, Autorité et Droits, de l'époque médiévale à nos jours, Monde Diplomatique, Paris, 2006.

Schejtman, A. and Berdegué, J. A.: Rural Territorial Development, IPPG Discussion Papers, 7, 2008.

Scholz, F.: The Theory of Fragmenting Development, Geographische Rundschau International, 1, 4-11, 2005.

Scott, A. J. and Storper, M.: Regions, Globalization, Development, Reg. Stud., 37, 579-593, 2003.
Shiva, V.: Soil, Not Oil. Environmental Justice in an Age of Climate Crisis, South End Press, Cambridge, 2008.

Sidaway, J. D.: Spaces of Postdevelopment, Prog. Hum. Geog., 31, 345-361, 2007.

Smith, N.: Uneven Development: the Capitalist Production of Space, Basil Blackwell, 1984.

Stöhr, W. and Taylor, D. (Eds.): Development from Above or Below ? The Dialectics of Regional Planning in Developing Countries, John Wiley and Sons Ltd., Chichester/New York, 1981.

Vanier, M.: Le pouvoir des territoires - Essai sur l'interterritorialité, Economica, Paris, 2008.

World Bank: World Development Report 2008. Agriculture for Development, Washington DC, 2007. 